\title{
Waste Nitrogen Excretion Via Amino Acid Acylation: Benzoate and Phenylacetate in Lysinuric Protein Intolerance
}

\author{
OLLI SIMELL, ILKKA SIPILÄ, JUKKA RAJANTIE, DAVID L. VALLE, AND \\ SAUL W. BRUSILOW \\ Children's Hospital, University of Helsinki, SF-00290 Helsinki, Finland; and Department of Pediatrics, The \\ Johns Hopkins University School of Medicine, Baltimore, Maryland 21205
}

\begin{abstract}
Benzoate and phenylacetate improve prognosis in inherited urea cycle enzyme deficiencies by increasing waste nitrogen excretion as amino acid acylation products. We studied metabolic changes caused by these substances and their pharmacokinetics in a biochemically different urea cycle disorder, lysinuric protein intolerance (LPI), under strictly standardized induction of hyperammonemia. Five patients with LPI received an intravenous infusion of $6.6 \mathrm{mmol} / \mathrm{kg} \mathrm{L}$-alanine alone and separately with $2.0 \mathrm{mmol} / \mathrm{kg}$ of benzoate or phenylacetate in $90 \mathrm{~min}$. Blood for ammonia, serum urea and creatinine, plasma benzoate, hippurate, phenylacetate, phenylacetylglutamine, and amino acids was obtained at $0,120,180$, and $\mathbf{2 7 0}$ min. Urine was collected in four consecutive 6-h periods. Alanine caused hyperammonemia: maximum increase $107,28-411 \mu \mathrm{M}$ (geometric mean, 95\% confidence interval); ammonia increments were nearly identical after alanine + benzoate $(60,17-213 \mu \mathrm{M})$ and alanine + phenylacetate $(79,13-467 \mu \mathrm{M})$ (NS). Mean plasma benzoate was $6.0 \mathrm{mM}$ when extrapolated to the end of alanine + benzoate infusions; phenylacetate was $4.9 \mathrm{mM}$ at the end of alanine + phenylacetate. Transient toxicity (dizziness, nausea, vomiting) occurred in four patients at the end of combined infusions, and we suggest upper therapeutic plasma concentrations of $4.5 \mathrm{mM}$ for benzoate and 3.5 $\mathrm{mM}$ for phenylacetate. Benzoate and phenylacetate then decreased following first-order kinetics with $t_{1 / 2}$ s of 273 and $254 \mathrm{~min}$, respectively. Maximal plasma hippurate $(0.24,0.14-0.40 \mathrm{mM})$ was lower than maximal phenylacetylglutamine $(0.48,0.22-1.06 \mathrm{mM}, p=0.008)$. Orotic acid excretion was $5.62,1.84-17.14 \mu \mathrm{mol} / \mathrm{kg}$ per $\mathrm{h}$ after alanine, but only $1.07,0.04-25.62 \mu \mathrm{mol} / \mathrm{kg}$ per $\mathrm{h}$ after alanine + benzoate $(p<0.151)$ and $2.74,0.01-16.25 \mu \mathrm{mol} /$ $\mathrm{kg}$ per $\mathrm{h}$ after alanine + phenylacetate $(p<0.016)$. Urea excretions were in the same range after all loads. Urinary hippurate nitrogen after alanine + benzoate and phenylacetylglutamine nitrogen after alanine + phenylacetate accounted for an average of 12 and 22 of that in urea in the first $6 \mathrm{~h}$. Of the benzoate and phenylacetate given, 65 and $51 \%$ were excreted in $24 \mathrm{~h}$ as hippurate and phenylacetyl-
\end{abstract}

Received December 10, 1985; accepted June 6, 1986.

Address for correspondence and reprint requests Dr. Olli Simell, Children's Hospital, University of Helsinki, 00290 Helsinki, Finland.

This study was supported by the Finnish Academy, by the Sigrid Jusélius Foundation and Foundation for Pediatric Research, Finland, and by Grants ROIHD-11134, MOI-RR-00052, and KO7-NS-00342 from the National Institutes of Health, by the Randi Klavan Memorial Fund, and by the Kittering Family Foundation. O.S. was a Visiting Scientist at the McGill University-Montrea Children's Hospital, sponsored by the Medical Research Council of Canada, during preparation of the manuscript. D.L.V. was an investigator in the Howard Hughes Medical Institutc. glutamine, respectively; less than $3.5 \%$ appeared unchanged in urine. (Pediatr Res 20: 1117-1121, 1986)

\section{Abbreviations}

LPI, lysinuric protein intolerance

iv, intravenous

In 1914 , Lewis (1) showed that benzoate modifies waste nitrogen excretion by decreasing production of urea via excretion of waste nitrogen as the acylation product of glycine with benzoate, i.e. hippurate. A few years later (2) phenylacetate was noted to be another efficient acylating agent, combining with glutamine to form phenylacetylglutamine. Excretion of these nitrogenous products decreases the requirement for urea synthesis. Despite these observations, these alternative ways of waste nitrogen excretion were not used clinically until the encouraging results in the treatment of inborn errors of the urea cycle were reported (3-9).

In life-threatening hyperammonemia measurements of the effects and metabolism of benzoate and phenylacetate are difficult if not impossible. We thus selected to test these substances in LPI, a disease with typical clinical picture $(10,11)$, wellcharacterized hyperammonemia, and defective transport of the diamino acids at the basolateral membrane of the intestinal (12$14)$, renal $(15,16)$, and probably liver $(17,18)$ epithelial cells. We gave the patients an iv alanine load, which leaves healthy subjects unaffected but causes moderate hyperammonemia in the patients, either alone or together with benzoate or phenylacetate. The results indicate that hippurate and phenylacetylglutamine nitrogen excretions accounted for over 10 and $20 \%$, respectively, of the amount of nitrogen excreted in urea in the first $6 \mathrm{~h}$. Neither one of these substances was able to abolish alanine-induced hyperammonemia in these patients, although orotic aciduria diminished.

\section{MATERIALS AND METHODS}

Patients. Five Finnish children (see the legend of Fig. 1; a sister-brother pair, otherwise no consanguinity between the patients) with a mean age (range) of $8.8(2.8-12.6) \mathrm{yr}$, weight for age of $-1.6[-0.9-(-3.2)] \mathrm{SD}$ and height for age of $-2.4[-1.3-$ $(-4.1)]$ SD and homozygous for LPI were studied after informed consent and acceptance of the study by the ethics committee of the hospital.

The patients were of normal intelligence, had hepatosplenomegaly, hypotrophic muscles, osteoporosis, and aversion to protein-rich food. They excreted massive amounts of lysine and less 

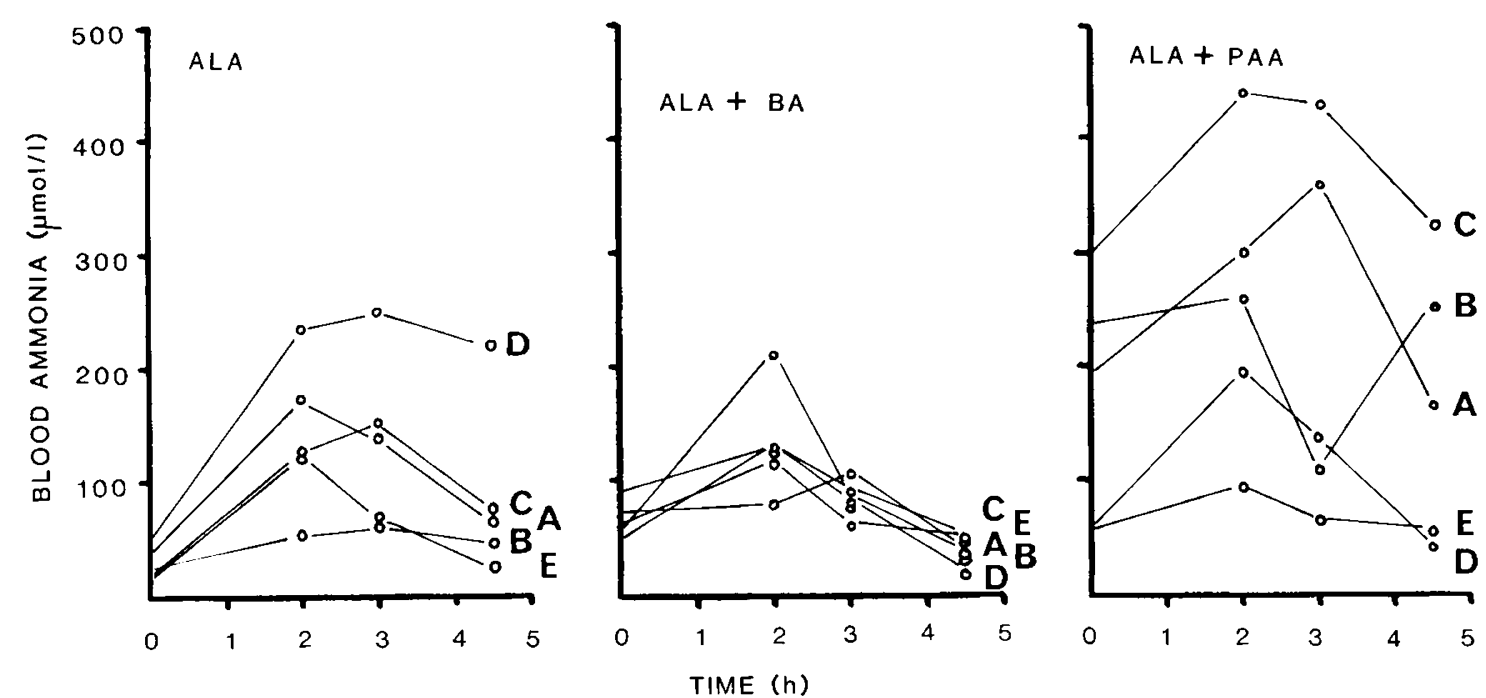

Fig. 1. Blood ammonia responses to $6.6 \mathrm{mmol} / \mathrm{kg}$ loads of alanine infused iv in $90 \mathrm{~min}$ either alone $(A L A)$ or together with $2.0 \mathrm{mmol} / \mathrm{kg}$ of benzoate $(A L A+\mathrm{BA})$ or phenylacetate (ALA + PAA) to five Finnish patients with lysinuric protein intolerance. For identification, the patients are named from $\mathrm{A}$ to $\mathrm{E} ; \mathrm{A}$ is the sister of $\mathrm{B}$.

of arginine and ornithine. All except one patient with recent diagnosis had been on citrulline supplementation, $0.5 \mathrm{mmol} / \mathrm{g}$ of daily dietary protein. Even on this regimen the protein intake had remained low $(12,19)$. The citrulline supplementation was stopped $48 \mathrm{~h}$ before the infusion studies.

The infusions were started after an overnight fast at $0900 \mathrm{~h}$, and no food was allowed during the first $6 \mathrm{~h}$. L-Alanine, 6.6 $\mathrm{mmol} / \mathrm{kg}$, was given iv as a $5 \%$ aqueous solution in $90 \mathrm{~min}$, followed by $0.9 \%$ saline, $200 \mathrm{ml} / \mathrm{m}^{2}$ of body surface area per $\mathrm{h}$ for additional $4.5 \mathrm{~h}$. This load causes a rapid increase in serum urea in healthy controls but blood ammonia and urinary orotic acid excretion remain unchanged (19). A similar infusion of alanine was given to each patient together with $2.0 \mathrm{mmol} / \mathrm{kg}$ of sodium benzoate, and on a separate day, with $2.0 \mathrm{mmol} / \mathrm{kg}$ of sodium phenylacetate.

Blood and urine samples. Blood for ammonia, serum urea and creatinine, plasma benzoate, hippurate, phenylacetate, phenylacetylglutamine, and amino acids was drawn at $0,90,120,180$, and $270 \mathrm{~min}$. Urine was collected in four consecutive 6 -h periods. Blood samples were immediately placed on ice and processed for measurement or storage at $-20^{\circ} \mathrm{C}$. Urine was collected on ice and frozen at the end of each collection.

Measurements. Blood ammonia was measured with an ammonia specific electrode (Orion Research Inc., Cambridge, MA) (20). Plasma and urinary benzoic acid, hippuric acid, phenylacetic acid, and phenylacetylglutamine were measured by reverse phase liquid chromatography with the use of a Waters $C_{18}$ column, with a $20 \%$ methanol solution in $0.01 \mathrm{M}$ acetate buffer, $\mathrm{pH} 3$, as an eluant. Plasma and urinary amino acids were quantitated with a Beckman $121 \mathrm{M}$ Amino Acid Analyzer using lithium buffers and norleucine as internal standard.

Statistical analysis. Values are expressed, if not otherwise stated, as geometric means with $95 \%$ confidence limits. For statistical evaluation, Mann-Whitney's U test was used.

Urinary values are expressed normalized to body weight. Results normalized to creatinine excretion gave little new information and were omitted.

\section{RESULTS}

Clinical symptoms. The youngest patient was pale and floppy for $1 \mathrm{~h}$ after alanine load, but others tolerated alanine-induced hyperammonemia without symptoms. Four patients, including the youngest one, had symptoms at the end of loads containing benzoate or phenylacetate. Three complained of dizziness and two vomited at the end of alanine + benzoate loads, and three were pale and dizzy after alanine + phenylacetate. The symptoms disappeared in 45-60 min.

Blood ammonia. The fasting blood ammonia concentration was normal $(70 \mu \mathrm{M})$ in 11 of the 15 measurements, and elevated in four (Fig. 1). The three hyperammonemic values at the beginning of the alanine + phenylacetate infusions were in patients having just arrived at the hospital in an overnight train; their ammonia increments were well within the range of the other subjects. Ammonia values usually peaked at $120 \mathrm{~min}$. The geometric mean of peak increments was slightly higher after alanine $(107,28-411 \mu \mathrm{M})$ than after alanine + benzoate $(60,17-$ $213 \mu \mathrm{M}, \mathrm{NS})$ and alanine + phenylacetate $(79,13-467 \mu \mathrm{M}, \mathrm{NS})$. The concentrations returned to basal values in all except one subject by $270 \mathrm{~min}$.

Serum urea and creatinine. The increase in the geometric mean values of serum urea after alanine (from 4.5 to $5.1 \mathrm{mM}$ ) and alanine + benzoate (from 6.6 to $8.3 \mathrm{mM}$ ) loads was caused by rising values in one patient. The values were stable in the others. Urea increased in this patient also after alanine + phenylacetate load.

Serum creatinine fluctuated slightly and randomly in the individual patients. The log mean values remained stable after alanine, increased after alaninae + benzoate, and decreased slightly after alanine + phenylacetate.

Plasma benzoate and hippurate. Plasma benzoate peaked $2 \mathrm{~h}$ after the start of the infusion and decreased linearly with a mean $t_{1 / 2}$ of 273 min (Fig. 2). By extrapolation, benzoate concentration at the end of infusion (at $90 \mathrm{~min}$ ) was $6.01,5.17-6.98 \mathrm{mM}$.

Plasma hippurate levels peaked $120 \mathrm{~min}$ after start of the infusions $(0.24,0.14-0.40 \mathrm{mM})$ and remained nearly stable for the next $3 \mathrm{~h}$ (Fig. 2), implying that synthesis from benzoate, distribution between plasma and other compartments and elimination were balanced, despite continuous decrease in plasma benzoate concentration. At all time points, the hippurate concentrations were less than $10 \%$ those of benzoate.

Plasma phenylacetate and phenylacetylglutamine. Peak plasma concentration of phenylacetate was at 120 min after the alanine + phenylacetate infusion (Fig. 3) and was significantly $(p=0.008)$ below the concentration of plasma benzoate reached after the alanine + benzoate load. The disappearance curve of phenylacetate from plasma was linear with a $t_{1 / 2}$ of $254 \mathrm{~min}$, similar to that of benzoate. By extrapolation, phenylacetate concentration was $4.77,3.71-6.11 \mathrm{mM}$ at the end of the infusion. 
Plasma phenylacetylglutamine values were stable in 180- and 270-min samples in two subjects but still increasing in three at 270 min (Fig. 3). Mean value thus peaked at $270 \mathrm{~min}$; concentration peaks $(0.48,0.22-1.06 \mathrm{mM})$ were above those of hippurate after alanine + benzoate $(p=0.008)$ (Figs. 2 and 3). Phenylacetylglutamine/phenylacetate percentages (linear means \pm
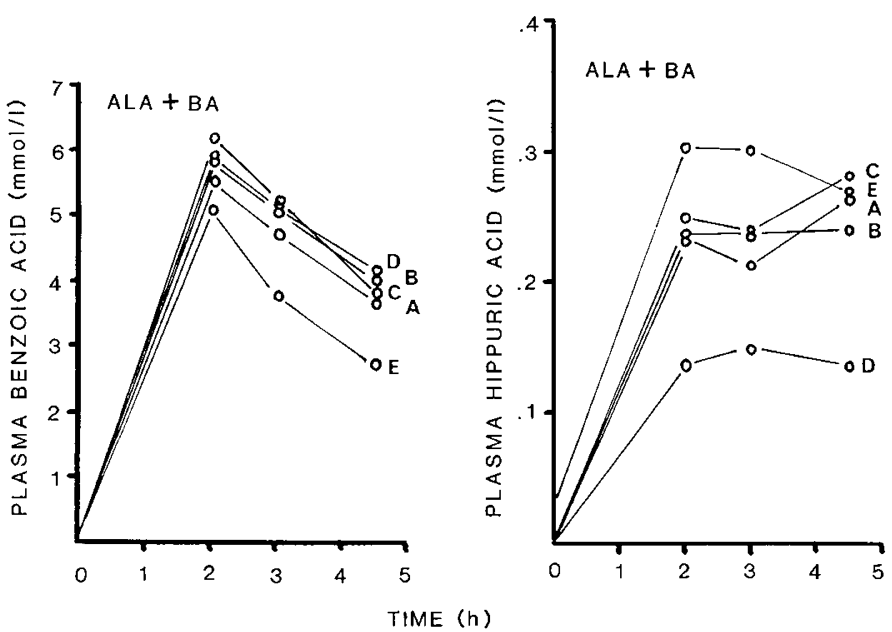

Fig. 2. Plasma benzoate and hippurate after alanine + benzoate loads in patients with lysinuric protein intolerance. For details see legend to Figure 1.
SD), $7 \pm 2,12 \pm 4$, and $19 \pm 10$ at the three measurement points (Fig. 3), were clearly above the hippurate/benzoate percentages after alanine + benzoate infusions (Fig. 2).

Plasma amino acids. Plasma alanine concentrations at the four measurement times and peak increments $(5.86,3.56-9.67$; $6.39,2.99-13.65$ and $4.66,1.05-20.70 \mathrm{mM}$ ) differed insignificantly after the three loads. Infusion of alanine caused an initial rise in plasma glycine concentration in all patients, whereas glycine increased in only three patients after alanine + benzoate and in four patients after alanine + phenylacetate. The peak increments in plasma glutamine + glutamic acid were $1.08,0.25$ $4.70 ; 0.84,0.26-2.71$; and $0.22,0.16-2.99 \mathrm{mM}(\mathrm{NS})$ after the three loads, respectively. Plasma proline concentrations increased and plasma citrulline rose slightly after alanine and alanine benzoate loads but decreased after alanine + phenylacetate. Arginine, ornithine, and lysine remained unchanged. Plasma concentrations of several other amino acids were slightly higher at $120 \mathrm{~min}$ as compared with the fasting value but responses were similar after all three loads.

Orotic acid excretion. The patients excreted 10 times more orotic acid during the first 6 -h collection after the alanine load (5.62, 1.84-13.14 $\mu \mathrm{M} / \mathrm{kg}$ per h) (Fig. 4) than they do in their daily urine (17). Addition of benzoate or phenylacetate to the infusion decreased this value to $19 \%(1.07,0.04-25.6 \mu \mathrm{mol} / \mathrm{kg}$ per $\mathrm{h}, p=0.151)$ and $49 \%(2.74,0.01-16.25 \mu \mathrm{mol} / \mathrm{kg}$ per $\mathrm{h}, p$ $=0.016)$ respectively, of alanine alone.

Urea excretion. Twenty-four-h urea excretion was $8.36,4.51-$ $15.49 \mathrm{mmol} / \mathrm{kg}$ after alanine, as compared with $9.30,6.12-14.13$ $\mathrm{mmol} / \mathrm{kg}$ after alanine + benzoate (NS) and 7.99, 4.22-15.15 $\mathrm{mmol} / \mathrm{kg}$ after alanine + phenylacetate (NS) with highest values in the first two 6-h collections (data not shown).
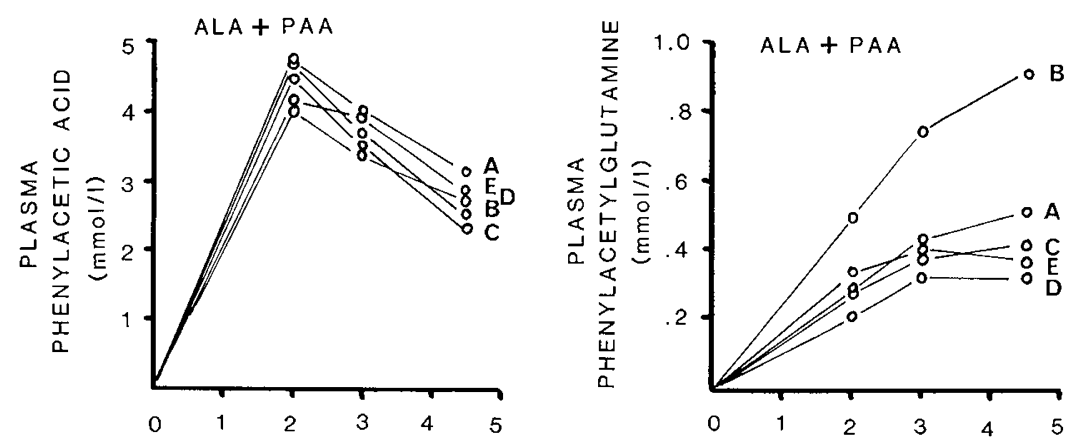

$\operatorname{TIME}(h)$

Fig. 3. Plasma phenylacetate and phenylacetylglutamine concentrations after alanine + phenylacetate loads in patients with lysinuric protein intolerance. For details see legend to Figure 1.
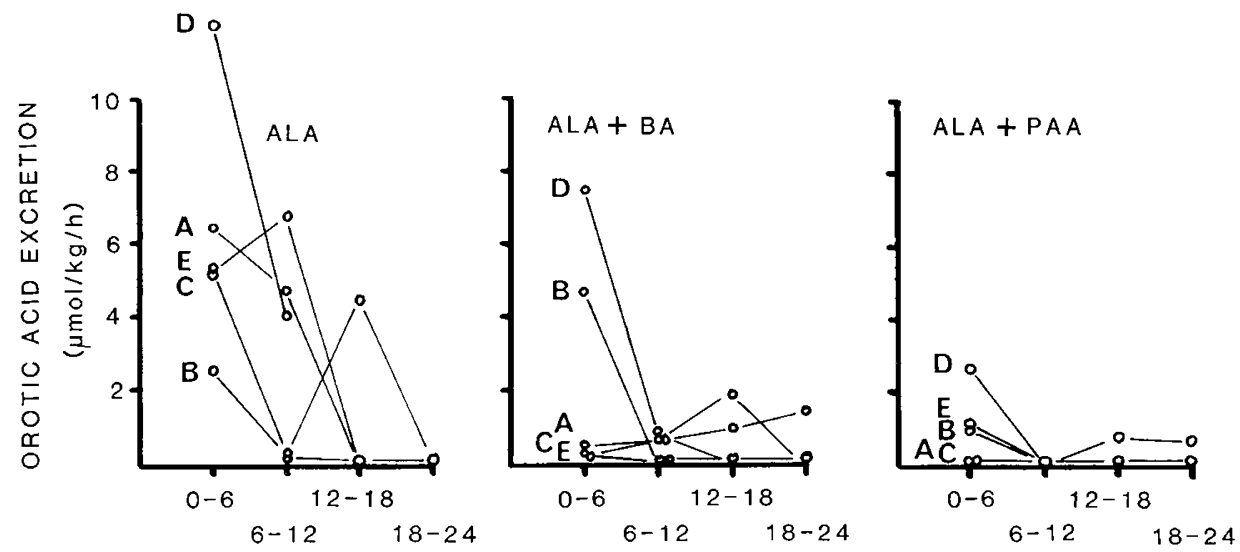

COLLECTION HOURS

Fig. 4. Urinary orotic acid excretions after alanine, alanine + benzoate, and alanine + phenylacetate infusions in patients with lysinuric protein intolerance. Urine was collected for four consecutive 6-h periods. For details of the infusions see legend to Figure 1. 
Benzoate and hippurate excretion. Less than $2 \%$ of the administered dose of benzoate appeared unchanged in the urine in 24 h. Hippurate excretion peaked in the first 6-h collection, decreased steadily and then was in the range of basal excretion in the last collection (Fig. 5). The combined amount of benzoate and hippurate excreted in $24 \mathrm{~h}(1.33,0.71-2.52 \mathrm{mmol} / \mathrm{kg})$ accounted for $67,35-126 \%$ of the benzoate dose given.

Phenylacetate and phenylacetylglutamine excretion. The amount of phenylacetate excreted unchanged in $24 \mathrm{~h}$ was 61,9 $425 \mu \mathrm{mol} / \mathrm{kg}$ or $3,0.4-21 \%$ of the dose infused. Excretion peaked in the first collection period, and approached zero values in the third and fourth collections.

For unknown reasons, measured urinary phenylacetylglutamine excretion in one patient markedly exceeded the infused dose of phenylacetate (Fig. 5). When her data are deleted from the results, $809,297-2200 \mu \mathrm{mol}$ or $40,15-110 \%$ of infused phenylacetate was excreted as phenylacetylglutamine in $24 \mathrm{~h}$. The major part of phenylacetylglutamine excretion occurred within $12 \mathrm{~h}$ but small amounts continued to be excreted even in the last collection.

Molar excretions of the acylation products (hippurate and phenylacetylglutamine) by the patient group were almost identical (Fig. 5) but "hippurate excretors" and "phenylacetylglutamine excretors" differed. Further, excretions of the acylation products did not correlate with orotic acid excretions, or peak or mean blood ammonic levels in individual patients.

Amino acid excretion. Mean 24-h alanine excretion was less than $2 \%$ of the administered dose and identical after the three

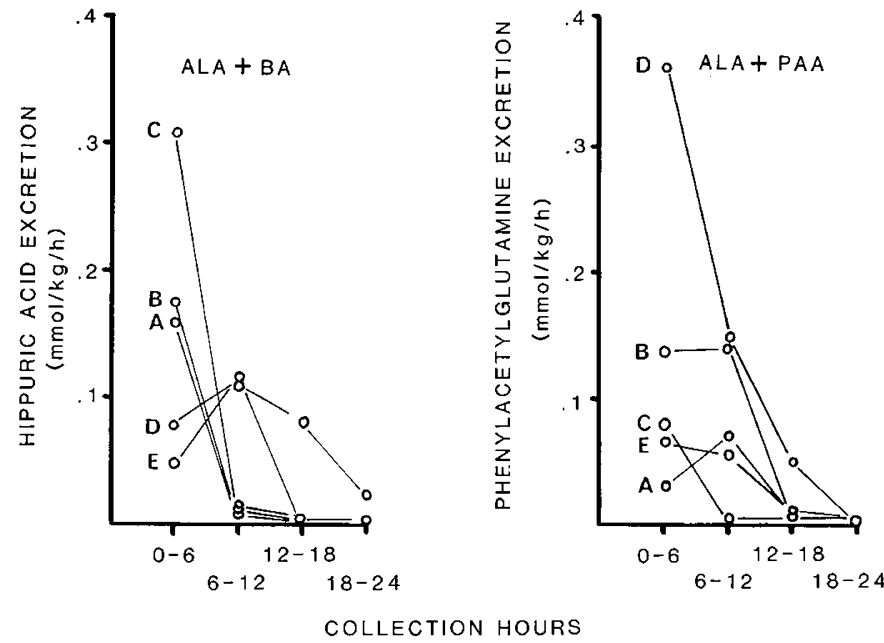

Fig. 5. Urinary hippurate excretion after alanine + benzoate loads and phenylacetylglutamine excretion after alanine + phenylacetate loads in patients with lysinuric protein intolerance. For details see the legend to Figure 1. loads. Excretion of alanine and other amino acids, including ornithine, arginine, and lysine was increased in the first collection, but returned to basal rates (data not shown).

Relative nitrogen excretions. The major part of urinary nitrogen output occurred as urea, but excretion as hippurate after alanine + benzoate and as phenylacetylglutamine after alanine + phenylacetate formed 11.5 and $22.1 \%$ of the urea nitrogen in the first collection period, respectively (Table 1). The excretion of nitrogen in other measured constituents of the urine, including orotic acid, was small after all loads.

\section{DISCUSSION}

Toxic dosage or plasma concentrations associated with acute toxicity after intravenous benzoate or phenylacetate are currently poorly known. The clinical responses (dizziness, nausea, vomiting) in our patients after the infusions of alanine + benzoate and alanine + phenylacetate suggest that the $2.0 \mathrm{mmol} / \mathrm{kg}$ dose is likely to cause symptoms in the majority of subjects. However, simultaneous hyperammonemia may have influenced the clinical symptoms. A dose between 1.5-1.8 mmol/ $\mathrm{kg}$, given iv in 90 min during a hyperammonemic crisis is probably safe, and the plasma concentrations reached should perhaps not exceed 4.0 $4.5 \mathrm{mM}$ for benzoate or $3.0-3.5 \mathrm{mM}$ for phenylacetate (calculated by extrapolating the mean plasma curves of these substances after the loads to the assumed peak concentration at the end of the infusion, minus $30 \%$ ). The calculated iv dose is within the range now safely used in patients with urea cycle enzyme deficiencies (8). Plasma concentrations measured in such patients imply that somewhat higher peak phenylacetate values (exceeding $4 \mathrm{mM}$ ) are acceptable.

The $t_{1 / 2}$ values in plasma for both benzoate and phenylacetate were short and almost identical, suggesting fast metabolism and distribution into tissues. Our results clearly indicate that the main metabolic pathway of these substances is via conjugation to hippurate and phenylacetylglutamine, respectively. Comparison of plasma benzoate and hippurate concentrations after the alanine + benzoate infusions (Fig. 2) suggests that benzoate concentration was not rate-limiting for acylation and lower concentrations might be as efficient for hippurate production without causing side effects. Plasma phenylacetate values after the alanine + phenylacetate infusions also remained high for a long period, and excretion of the acylation product continued for even longer.

The $6.6 \mathrm{mmol} / \mathrm{kg}$ dose of L-alanine iv has been experimentally found suitable for induction of mild hyperammonemia in LPI (10). In theory, addition of $2.0 \mathrm{mmol} / \mathrm{kg}$ of benzoate or phenylacetate to the load optimally leads to stoichiometric elimination of 2 and $4 \mathrm{mmol} / \mathrm{kg}$ of nitrogen as hippurate and phenylacetylglutamine, respectively. Because lower doses of alanine are tolerated without hyperammonemia in LPI, we assumed that these benzoate and phenylacetate doses, despite of the apparent non-

Table 1. Nitrogen excretion ( $\mu$ mol/ $\mathrm{kg}$ body wt per $h$, or percent of nitrogen excreted in urea) in five patients with lysinuric protein intolerance in the first 6-h collections after loads of alanine, alanine + benzoate, and alanine + phenylacetate*

\begin{tabular}{|c|c|c|c|c|c|c|}
\hline \multirow[b]{2}{*}{$\mathrm{N}$ excreted in } & \multicolumn{6}{|c|}{ Load } \\
\hline & Alanine & $\%$ & Alanine + benzoate & $\%$ & Alanine + phenylacetate & $\%$ \\
\hline Urea & $784 ; 364-1970$ & 100 & $1100 ; 400-3020$ & 100 & $841 ; 396-3020$ & 100 \\
\hline Hippurate & & & $126 ; 29-542$ & 11.5 & $1.6 ; 0.2-11.1$ & 0.2 \\
\hline $\begin{array}{l}\text { Phenylacetylgluta- } \\
\text { mine }\end{array}$ & & & & & $186 ; 28-1200$ & 22.1 \\
\hline Orotic acid & $11.2 ; 3.7-34.3$ & 1.4 & $2.1 ; 0.1-51.2$ & 0.2 & $5.5 ; 0.0-32.5$ & 0.7 \\
\hline Alanine & $11.8 ; 0.8-167.2$ & 1.5 & $16.2 ; 2.0-129.2$ & 1.5 & $14.2 ; 1.9-104.4$ & 1.7 \\
\hline Glycine & $3.6 ; 0.3-55.9$ & 0.5 & $1.8 ; 0.1-43.3$ & 0.2 & $1.9 ; 1.5-19.9$ & 0.2 \\
\hline $\begin{array}{l}\text { Glutamine + glutamic } \\
\text { acid }\end{array}$ & $18.7 ; 3.5-101.1$ & 2.4 & $23.9 ; 1.3-92.5$ & 1.3 & $4.5 ; 0.5-38.1$ & 0.5 \\
\hline Lysine & $8.7 ; 6.5-11.6$ & 1.1 & $10.4 ; 1.3-85.0$ & 1.0 & $14.4 ; 4.0-51.1$ & 1.7 \\
\hline Creatinine & $8.6 ; 10.8-26.1$ & 1.1 & $14.6 ; 2.3-92.5$ & 1.3 & $17.4 ; 8.4-35.9$ & 2.1 \\
\hline
\end{tabular}

\footnotetext{
* Values are log means; $95 \%$ confidence limits. Percentages are calculated for the means.
} 
stoichiometry, would prevent the induced hyperammonemia. Instead, in this study, blood ammonia values and urinary orotic acid excretion were only moderately diminished by addition of benzoate or phenylacetate to the alanine load, suggesting that hyperammonemia, carbamyl phosphate, and, subsequently, orotic acid production occur rapidly after alanine infusion and are not efficiently abolished by simultaneous infusion of the acylating agents. Induction of hyperammonemia by protein intake (5$9,21)$ probably leads to more even distribution of nitrogen in metabolic compartments and, consequently, may be associated with better responses to treatment with the acylating agents. Interestingly, correlation of orotic acid excretion with blood ammonia was good in these experiments as in previous studies (22-23)

Our findings of the excretion rates of hippurate and phenylacetylglutamine after the loads differ somewhat from earlier findings in healthy subjects. Lewis's volunteer, receiving $10 \mathrm{~g}$ of sodium benzoate orally, excreted $23 \%$ of urinary total nitrogen as hippurate, but an equimolar decrease occurred in urea + ammonia nitrogen excretions. We did not measure total nitrogen output in our patients, but hippurate nitrogen excretion was $12 \%$ of urea nitrogen excreted in the first $6 \mathrm{~h}$ after the load. We also found that $54 \%$ of the single phenylacetate dose was excreted as phenylacetylglutamine in $24 \mathrm{~h}$ after the load. Earlier Ambrose et al. (24), after having administered $5-7 \mathrm{~g} /$ day of phenylacetate to a healthy man, found $98 \%$ of the dose in urine as phenylacetylglutamine. In another study (25), $91 \%$ of the $85 \mathrm{mg} / \mathrm{kg}$ dose was excreted in the urine as phenylacetylglutamine.

In patients with urea cycle enzyme deficiency who have received benzoate or phenylacetate treatment with proper measurement of nitrogen excretion (3-5, 7-9), urea excretion remained unchanged even though the total nitrogen excretion increased by approximately the amount accountable for hippurate or phenylacetylglutamine, just as in our experiments. The cause for the discrepancy in the urea excretions after administration of benzoate or phenylacetate in healthy subjects and in patients with urea cycle failure remains open. However, it suggests that urea excretion in urea cycle diseases (often with a close to zero enzyme activity of the cycle in vitro) cannot be easily changed and represents nitrogen coming from another pool than the one affected in similar experiments in healthy subjects $(8,9)$.

After a single dose of benzoate or phenylacetate with alanine, the acylation products formed 12 and $22 \%$ of the urea nitrogen in the urine immediately after the dose. During prolonged administration the percentages are probably higher (3-5, 7-9). The fast disappearance from plasma of both benzoate and phenylacetate suggests that frequent oral doses or continuous infusion are optimal ways for their administration.

In summary, this study shows that waste nitrogen excretion as hippurate or phenylacetylglutamine can be induced in patients with LPI by infusion of benzoate or phenylacetate. Neither one of these substances, when added to an iv alanine infusion, is able to abolish the resulting hyperammonemia and orotic aciduria in the patients. In hyperammonemic crisis, addition of benzoate, phenylacetate, or both to the iv ornithine or arginine or oral or iv citrulline treatment of LPI $(10,11)$ may prove helpful, just as they are effective in hyperammonemic urea cycle enzyme deficiencies (3-9).
Acknowledgments. The skillful technical assistance of Ms. Marjatta Viikari, Ellen H. Gordes, and Evelyn Bull is acknowledged. The authors thank Huguette Rizziéro and Lynne Prevost (McGill University-Montreal Children's Hospital Research Institute) for preparing the typescript.

\section{REFERENCES}

1. Lewis HB 1914 Studies in the synthesis of hippuric acid in the animal organism. J Biol Chem 18:225-231

2. Shiple GT, Sherwin CP 1922 Synthesis of amino acids in animal organisms. I Synthesis of glycocoll and glutamine in the human organism. J Am Chem Soc 44:618-624

3. Brusilow S, Valle DL, Batshaw ML 1979 New pathways of nitrogen excretion in inborn errors of urea synthesis. Lancet 1:452-454

4. Brusilow S, Tinker J, Batshaw ML 1980 Amino acid acylation: A mechanism of nitrogen excretion in inborn errors of urea synthesis. Science 207:659661

5. Batshaw ML, Painter MJ, Sproul GT, Schafer IA, Thomas GH, Brusilow S 1981 Therapy of urea cycle enzymopathies: Three case studies. Johns Hopkins Med J 148:34-40

6. Smith I 1981 The treatment of inborn errors of the urea cycle. Nature 291:378380

7. Batshaw, ML, Brusilow S, Waber L,Blom W, Brubakk AM, Burton B, Cann H, Kerr D, Mamunes P, Myerberg D, Schafer I 1982. Treatment of inborn errors of urea synthesis. N Engl J Med 306:1387-1392

8. Brusilow SW, Danney M, Waber LJ, Batshaw M, Burton B, Levisky L, Roth K, McKeethren C, Ward J 1984 Treatment of episodic hyperammonemia in children with inborn errors of urea synthesis. N Engl J Med 310:16301634

9. Brusilow W 1984 Arginine, an indispensable amino acid for patients with inborn errors of urea synthesis. J Clin Invest 74:2144-2148

10. Simell O, Perheentupa J, Rapola J, Visakorpi JK, Eskelin LE 1975 Lysinuric protein intolerance. Am J Med 59:229-240

11. Rajantie J. Simell O. Rapola J. Perheentupa J 1980 Lysinuric protein intolerance: a two-year trial of dietary supplementation therapy with citrulline and lysine. J Pediatr 97:927-932

12. Rajantie J. Simell O, Perheentupa J 1980 Intestinal absorption in lysinuric protein intolerance: impaired for diamino acids, normal for citrulline. Gut 21:519-524

13. Rajantie J. Simell O. Perheentupa J 1980 Basolateral membrane transport defect for lysine in lysinuric protein intolerance. Lancet 1:1219-1221

14. Desjeux J-F. Rajantie J, Simell O, Dumontier A-M., Perheentupa J 1980 Lysine fluxes across the jejunal epithelium in lysinuric protein intolerance. J Clin Invest 64:1382-1387

15. Simell O, Perheentupa J 1974 Renal handling of diamino acids in lysinuric protein intolerance. J Clin Invest 54:9-17

16. Simell O. Perheentupa J 1974 Defective metabolic clearance of plasma arginine and ornithine in lysinuric protein intolerance. Metabolism 23:691-701

17. Simell O 1975 Diamino acid transport into granulocytes and liver slices of patients with lysinuric protein intolerance. Pediatr Res 9:504-508

18. Rajantie J, Simell O, Perheentupa J 1983 "Basolateral" and mitochondrial membrane transport defect in the hepatocytes in lysinuric protein intolerance. Acta Paediatr Scand 72:65-70

19. Rajantie J 1981 Orotic aciduria in lysinuric protein intolerance: dependence on the urea cycle intermediates. Pediatr Res 15:115-119

20. Proelss HF, Wright BW 1973 Rapid determination of ammonia in a perchloric acid supernate from blood, by use of an ammonia-specific electrode. Clin Chem 19:1162-1169

21. Brusilow SW, Valle DL 1985 Identification of heterozygosity for ornithine transcarbamylase deficiency (OTCD). Pediatr Res 19:244A(abstr)

22. Kesner I 1965 The effect of ammonia administration on orotic acid excretion in rats. J Biol Chem 240:1722-1724

23. Milner JA, Visek WJ 1975 Urinary metabolites characteristic of urea-cycle amino acid deficiency. Metabolism 24:643-651

24. Ambrose AM. Power FW. Shervin CP 1933 Further studies on the detoxification of phenylacetic acid. J Biol Chem 101:669-675

25. James MO, Smith RL, Williams RT, Reidenberg M 1972 The conjugation of phenylacetate acid in man, sub-human primates and some none-primate species. Proc R Soc Lond [Biol] 182:25-35 